Moore, S. \& Stein, W. H. (195I). F. biol. Chem. 192, 663.

Osborne, T. B. \& Mendel, L. B. (1914). F. biol. Chem. 17, 325.

Ramarao, P. B., Metta, V. C. \& Johnson, B. C. (1957). Fed. Proc. 16, 397.

Rose, W. C. (1937). Science, 86, 298.

Rose, W. C., Smith, L. C., Womack, M. \& Shane, M. (1949). F. biol. Chem. r8r, 307.

Rosenberg, H. R. \& Rohdenburg, E. L. (1952). Arch. Biochem. Biophys. 37, $46 \mathrm{r}$.

Rosenberg, H. R., Rohdenburg, E. L. \& Baldini, J. T. (1954). Arch. Biochem. Biophys. 49, 263.

Sure, B. (1953). F. Nutr. 50, 235 .

Waddell, J. (1958). Processed Plant Protein Foodstuffs. New York: Academic Press Inc.

\title{
The use of Dolichos lablab and Lathyrus sativus in the making of taamiah (bean cakes) in Egypt
}

\author{
BY SABRY RIAD MORCOS AND AMAL MORGAN BOCTOR \\ Nutrition Research Unit, National Research Centre, Dokki, Cairo, Egypt \\ (Received 13 August 1958-Revised 17 November 1958)
}

In Egypt, where the consumption of animal foods is low, legumes and pulses occupy a prominent position in the national dietary. Broad beans and lentils come first in order of legume consumption.

Lately, however, home-grown lentils and broad beans have failed to meet local demand. The population is growing at an alarming rate, but the cultivable area remains about stationary.* To make matters worse the bean crop has lately been attacked periodically, on an unprecedented scale, by the vegetable parasite Orobanche crenata Forsk., known locally as halook, and also by some virus diseases. Both together adversely affect not only the yield but also the quality of the seed itself.

To understand the seriousness of the bean shortage one has to remember that broad beans (Vicia faba L.) are the basis of two most popular breakfast foods, stewed beans and bean cakes or taamiah. Crowded shops selling both articles are now found in all quarters of Cairo, though formerly their sale was restricted to poorer districts. This spreading popularity must also be contributing to the present high demand for broad beans. To relieve the shortage, the Ministry of Supply imports beans and lentils from China, Syria and Ethiopia.

Aware of the nutritional and financial situation, this Unit wished to supplement governmental effort by introducing two edible leguminous seeds that grow in the south, at present on a limited scale, in Quena and Assuan, both for human consumption and as animal fodder. The idea was to replace broad beans, either partly or completely, in some of the popular dishes by one of these two legumes and, should this measure be successful, to encourage their cultivation on a wider scale.

This is a description of an attempt to use the seeds of gueshrangaig, the Egyptian or hyacinth bean (Dolichos lablab L.) and gilban, the blue vetch (Lathyrus sativus L.) as substitutes for broad beans in the making of taamiah.

* In 1917 the population was 12795000 and cultivable land 5268528 acres, in 1957 the population was 24269500 and cultivable land 56954 II acres. 


\section{EXPERIMENTAL}

\section{Description of the seeds}

Seeds of the hyacinth bean are much eaten in the tropics (Winton, Moeller \& Winton, 1916). In Assuan and the Sudan they are made into a stew or are germinated before cooking: they are characterized by their flattened form and large hilum, and are uniformly reddish brown. The seeds of blue vetch are facetted and irregular in shape: the size is variable but they seldom exceed $5 \mathrm{~mm}$ in length.

Eight random samples of each of the two chosen seeds, and of two local varieties (foul baaly and foul meskawy) and one imported variety (foul habashy) of broad bean were analysed. The nitrogen content of seeds and prepared cakes was determined by the Kjeldahl method as modified by Gunning \& Arnold (cf. Bradstreet, 1940). The crude fat was determined by extraction in a Soxhlet apparatus with diethyl ether. For determination of calcium, phosphorus and iron in the ashed seeds and cakes, the methods of the Association of Official Agricultural Chemists (1955) were adopted. The results confirmed our belief that the seeds are similar in composition. Cakes were therefore made from both seeds and offered first to the personnel of the Centre for trial and later to the public. The reports were encouraging. The preparation of gueshrangaig and gilban cakes was by the procedure adopted for broad-bean cakes.

\section{Preparation of the cakes (taamiah)}

In Egypt Vicia faba is the bean from which taamiah is made, but in other countries the chick-pea (Cicer arietinum L.) may take its place. The decorticated bean is soaked in water overnight, surplus water is then drained off and onions, garlic, greens, including Allium kurrat, parsley and fresh coriander, also spices including pepper, coriander seeds and salt, are added to taste. The mixture is then crushed into a thick paste in a huge granite mortar of special construction. The crushing space is in the form of a hollow inverted cone and the pestle is a heavy iron rod, $5-7 \mathrm{~cm}$ in diameter and about I $\mathrm{m}$ long, having a short smooth tapered end which fits into the apex of the cone. The operator aims at crushing the ingredients against the sides of the cone with a circular rhythmic crushing movement of the pestle. The contents are kept within the crushing area with the help of a crude iron spatula.

When ready, the mass, which is uniformly greenish-white in colour, feels homogeneous and light because of entrained air; it is now carefully removed from the mortar and allowed to stand for some time. Fermentation, accompanied by the production of gas, usually sets in. It is encouraged by keeping the mass in a warm place. Gas formation helps good frying and gives the fried cake a spongy texture. If fermentation is slow, the same effect can be produced by the addition of a little bicarbonate of soda or baking powder.

The paste is finally cut into small pieces, $10-12 \mathrm{~g}$ in weight, made into flat disks up to $5 \mathrm{~cm}$ in diameter, or into balls, and fried in deep, hot cottonseed oil until the surface is uniformly browned, which takes from 2 to $4 \mathrm{~min}$.

Taamiah is usually eaten hot or warm and so is made fresh daily. The fried cake, if left in the air, rapidly loses its crispness, a quality valued much by the consumer. 
Sesame seed sometimes decorates the surface of the cake, to which it imparts a pleasant taste, and raw eggs may be mixed with the paste before frying. In either event the nutritive value is much enhanced (cf. Hassan \& Ayyadi, r955).

\section{RESULTS}

The results of the analysis of the beans are presented in Table $\mathrm{I}$.

The nitrogen contents of the two local varieties of broad bean (baaly and meskawy) was higher than those of the imported bean (habashy) and of gilban and gueshrangaig. Calcium also was low in gueshrangaig. In general, however, the composition of the three is closely similar and the differences should not appreciably affect the nutritive value of cakes made from the two seeds.

Table 2 shows the composition of taamiahs made from gilban and gueshrangaig compared with that of taamiah made from broad beans. The variable water content affects markedly the ultimate composition of the finished cake.

Table 3 gives the composition and calorie value of a piastre-worth of each of the three taamiahs. For those made from gilban and gueshrangaig the values were calculated on the basis of the market price at the time of the experiment and of the analyses of the samples prepared in the laboratory.

\section{DISCUSSION}

The two recommended seeds grow in poor sandy soil, where broad beans do not thrive, and stand drought and heat better. Stimulating their local production would therefore be sounder than trying to stimulate production of broad beans. In fact this measure can be attempted at once in Quena and Assuan, where the seeds are already cultivated and where there is now a need for increased bean production. The big irrigation and related industrial projects nearing completion in Assuan as well as those still in the preparatory stages will rapidly increase the population there. As might be expected, a nutrition problem has already arisen and will, no doubt, soon become acute. The composition of taamiah fits it to relieve the expected shortage, for not only is it delicious but it also provides the consumer with cheap calories. One piastre-worth of it, some bread and a dish of green salad, composed mainly of tomatoes, chopped onions and a little parsley, constitute the usual morning meal in towns. A taamiah sandwich is a regular snack during the day and after the cinema. It has become the fashion lately to serve it hot at cocktail and other parties in the cities.

\section{The question of lathyrism}

In countries where the lathyrus pea provides a significant part of the calorie intake, a disease known as lathyrism has been reported. It causes degenerative changes of the nervous system. Much work has been done on the aetiology of the disease; Young (1927), after a wide field survey of its distribution and of the conditions in India under which it develops, concluded that it is due to the ingestion of large amounts of Lathyrus odoratus L. and that the signs are not produced in the presence of vitamin A or its precursors. Mellanby (1934) fed dogs on the seeds of L. satious, but failed to produce 


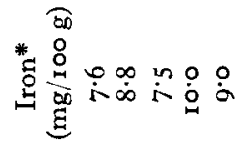

1. $\begin{aligned} & \text { * } \\ & 3\end{aligned}$

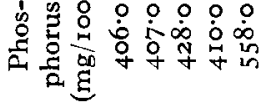

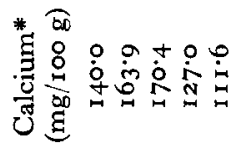

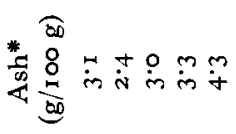

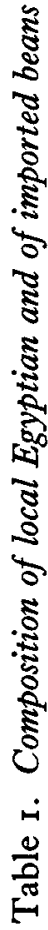

苔兽兽

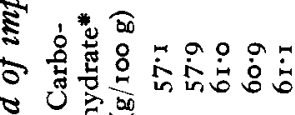

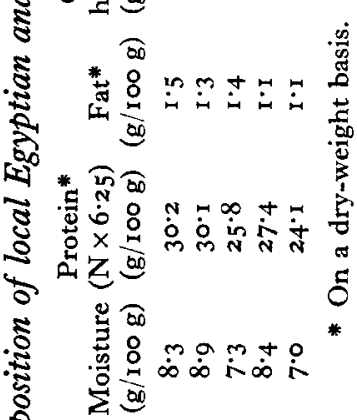

ह

氶

(

정

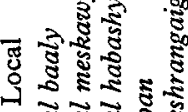

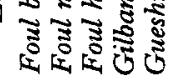

.

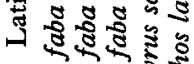

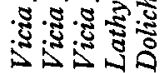

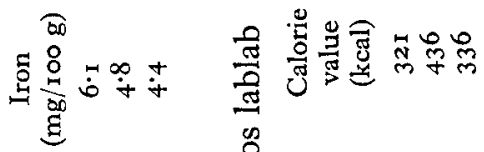

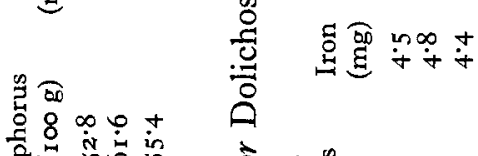

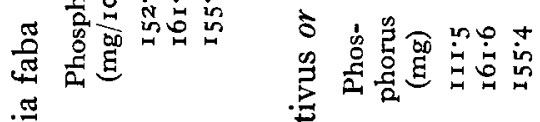

날

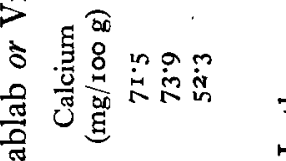

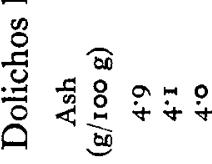

?

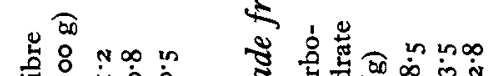

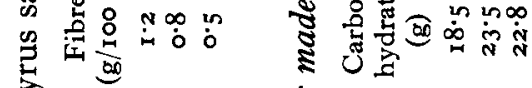

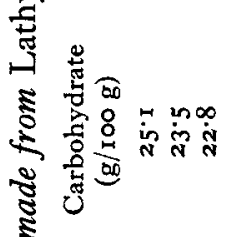

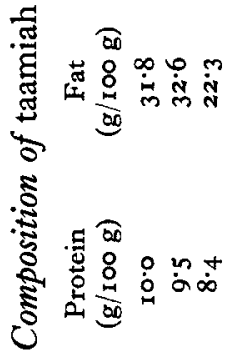

$\dot{s}$

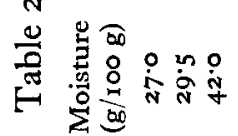

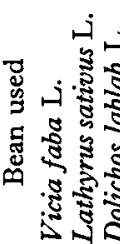

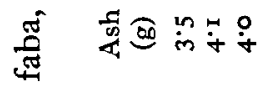

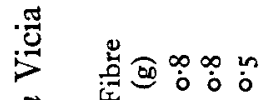

密

造

ᄂ I

透

$\frac{5}{3}$

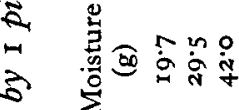

2

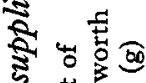

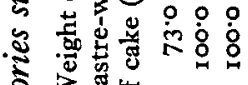

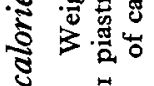

ฐ

之.

$\dot{m} \quad$ क⿺辶े
药 
any serious lesions of the nervous system. Lewis \& Esterer (1943) showed that lathyrism in young white rats was due to the ingestion of a diet containing $50 \%$ L. odoratus. Lewis, Fajans, Esterer, Shen \& Oliphant (1948) demonstrated that rats fed on L. sativus or L. cicera $\mathrm{L}$. at the $50 \%$ level grew well and showed no sign of lathyrism. Ponseti (I954) mentioned that Schilling \& Strong had isolated from L. odoratus a crystalline compound responsible for lathyrism.

Seeds of the local lathyrus were cultivated in the garden of the Centre. Both plant and seeds were sent for identification to experts of the Ministry of Agriculture. They reported that it was $L$. sativus, and their identification was confirmed in a private communication by Dr Vivi Tackholm, Professor of Systematic Botany, Faculty of Science, Cairo University, Cairo, Egypt, who affirms that this variety is the only one grown in Egypt. Moreover, no cases of lathyrism have ever been reported from Quena province, where gilban is used for human consumption.

\section{SUMMARY}

1. In Egypt, the fried broad-bean cake (taamiah) has been known and enjoyed for centuries as a popular, delicious and cheap food. Attempts to relieve the present bean shortage through importation were made by the Government at a high cost. Our work aimed at offering an alternative method of relief.

2. Eight samples of the seeds of Dolichos lablab (gueshrangaig) and Lathyrus sativus (gilban), two local legumes, and of locally grown and imported broad beans were analysed and their compositions compared. Taamiahs made from the three species of bean were also analysed.

3. It was concluded that Dolichos lablab and Lathyrus sativus were suitable substitutes for broad beans in the making of taamiah.

The authors thank Professor Dr Ali Hassan, Head of the Unit, for suggesting the work and for his continuous advice and constructive criticism.

\section{REFERENCES}

Association of Official Agricultural Chemists (1955). Official Methods of Analysis, 8th ed. Washington: Association of Official Agricultural Chemists.

Bradstreet, R. B. (1940). Chem. Rev. 27, 33 I.

Hassan, A. \& Ayyadi, M. A. S. (1955). F. Egypt. med. Ass. 38, 231.

Lewis, H. B. \& Esterer, M. B. (1943). Proc. Soc. exp. Biol., N.Y., 53, 263.

Lewis, H. B., Fajans, R. S., Esterer, M. B., Shen, C. W. \& Oliphant, M. (1948). F. Nutr. 36, 537.

Mellanby, E. (1934). Nutrition and Disease. Edinburgh: Oliver and Boyd.

Ponseti, I. V. (1954). F. Bone Ft. Surg. 36, A, 1031.

Winton, A. L., Moeller, J. \& Winton, K. B. (I916). The Microscopy of Vegetable Foods, and ed. New York: John Wiley \& Sons, Inc.

Young, T. C. M. (1927). Indian Y. med. Res. I5, 453. 